\title{
Sosialisasi Pengolahan Sampah Menjadi Energi Listrik Di Desa Sukawali, Kecamatan Pakuhaji, Tangerang
}

\author{
Yuliansyah $^{1}$; Agus Yogiyanto² ${ }^{2}$ Martin C. Fatah ${ }^{3}$; Ibnu Hajar ${ }^{4}$; Edy Ispranyoto ${ }^{5}$; \\ Supriadi Legino ${ }^{6}$; Sri Yayi $^{7}$
}

1, 2, 3, 4, 5, 6, 7 Sekolah Tinggi Teknik PLN, Departemen Teknik Elektro

${ }^{4}$ ibnu.hajar@sttpln.ac.id

\begin{abstract}
Waste is a problem faced by both big cities and suburbs and even rural areas also experience this waste problem. In the community service carried out by the PKM team, the Electrical Engineering lecturers at STT PLN Jakarta took the socialization of processing waste into electrical energy that will be carried out in Sukawali Village, Pakuhaji District, Tangerang, Banten. This activity was carried out in the form of lectures and presentations whose participants ranged from 30 to 40 participants consisting of village officials, $R W$ heads and administrators, $R T$ heads and administrators and invited people. This socialization will provide a solution to the waste problem in Sukawali Village, and generally in the City of Tangerang. The solution offered in this socialization is how waste is processed into energy through the stages of the gasification and briquetting process.
\end{abstract}

Keywords: waste, socialization, gasification and briquetting process, community service

\begin{abstract}
ABSTRAK
Sampah merupakan permasalahan yang dihadapi baik kota besar maupun kota-kota pinggiran bahkan pedesaan pun mengalami permasalahan sampah ini. Pada pengabdian kepada masyarakat yang dilaksanakan oleh tim PKM dosen teknik elektro STT PLN Jakarta mengambil kegiatan sosialisasi pengolahan sampah menjadi energi listrik yang akan dilaksanakan di Desa Sukawali, Kecamatan Pakuhaji, Tangerang, Banten. Kegiatan ini dilaksanakan dalam bentuk ceramah dan presentasi yang pesertanya berkisar $30-40$ peserta yang terdiri perangkat kelurahan, ketua-ketua $R W$ dan pengurus, ketua-ketua $R T$ dan pengurus dan masyarakat undangan. Sosialisasi ini akan memberikan solusi permasalah sampah yang ada di Desa Sukawali, dan umumnya di Kota Tangerang. Solusi yang ditawarkan pada sosialisasi ini adalah bagaimana sampah diolah menjadi energi dengan melalui tahapan proses gasifikasi dan briketisasi.
\end{abstract}

Kata Kunci: Sampah, Sosialisasi, Gasifikasi dan Briketisasi, Pengabdian Kepada Masyarakat (PKM) 


\section{PENDAHULUAN}

Persoalan pengelolaan sampah masih menjadi pekerjaan rumah besar bagi Indonesia. Riset terbaru Sustainable Waste Indonesia (SWI) mengungkapkan sbanyak 24 persen sampah di Indonesia masih tidak terkelola. Ini artinya, dari sekitar 65 juta ton sampah yang diproduksi di Indonesia tiap hari, sekitar 15 juta ton mengotori ekosistem dan lingkungan karena tidak ditangani. Sedangkan, 7 persen sampah didaur ulang dan 69 persen sampah berakhir di Tempat Pembuangan Akhir (TPA) [1].

Persoalan semakin bertambah. Sampah konsumsi warga perkotaan itu ternyata banyak yang tidak mudah terurai, terutama plastik. Semakin menumpuknya sampah plastik menimbulkan pencemaran serius. Kondisi ini disadari sebagian masyarakat dengan menumbuhkan upaya pengurangan sampah plastik [2]. Kanton plastik baru dapat terurai paling tidak selama lebih dari 20 tahun di dalam tanah. Jika kanton plastik itu berada di air, akan lebih sulit lagi terurai [2].

Permasalah sampah tidak terbatas di perkotaaan. Di kawasan pesisir dan juga pedalaman, sampah selalu menjadi masalah yang tidak terselesaikan [3]. Demikian juga Kota Tangerang, sampah yang dihasilkan masyarakat kota Tangerang sebanyak 1.500 ton sampah. Sedangkan sampah yang terangkut sekitar 1.000 ton sampah ke TPA Rawa Kucing oleh 165 armada truk dari 13 kecamatan [4].

Tempat Pembuangan Akhir (TPA) Rawa Kucing diharapkan bisa menjadi salah satu contoh pengelolaan yang baik secara teknologi, kelembagaan, maupun operasionalnya yang bisa didesain untuk dapat digunakan sebagai sumber energi melalui pengembangan pembangkit listrik tenaga sampah (PLTSa) [5].

Direktur Pengembangan Penyehatan Lingkungan Dodi Krispratmadi, mengatakan, salah satunya adalah merehabilitasi Tempat Pemrosesan Akhir (TPA) Rawa Kucing di Kecamatan Neglasari, Kota Tangerang, Provinsi Banten [5], yaitu dengan metode sanitary landfill, sampah dibuang dan ditumpuk di lokasi cekung, dipadatkan dan kemudian ditimbun dengan tanah sehingga tidak menimbulkan bau busuk, mencegah berkembangnya bibit penyakit serta ramah lingkungan. Selain itu bisa didesain untuk dapat digunakan sebagai sumber energi melalui pengembangan Pembangkit Listrik Tenaga Sampah (PLTSa).

Masyarakat pada umumnya, sudah terbiasa dengan kehidupan yang dijalaninya setiap hari, membuang sampah disembarang tempat, tidak peduli dengan kesehatan lingkungan, dan sebagainya. Karena kehidupan yang dijalaninya sudah seperti itu dan sudah berlangsung lama bahkan mungkin sejak masyarakat itu lahir, sehingga sudah merasa nyaman dengan kehidupan yang ada sekarang dan sangat susah move on dari keadaan sekarang.

Sampah yang merupakan masalah utama disetiap daerah baik itu perkotaan maupun pinggiran kota/pedesaan perlu penanganan yang serius dan tuntas sehingga tidak meninggalkan masalah bagi lingkungan.

Teknologi pengolahan sampah sudah banyak yang ditawarkan dari hal sederhana hingga teknologi canggih, misalnya teknologi pengolahan sampah waste to energy (WTE) yaitu mengolah sampah menjadi energi listrik (PLTSa), namun biasanya masih menyisakan residu yang dapat mengotori lingkungan.

Oleh karena permasalahan tersebut di atas, pada sosialisasi pengolahan sampah menjadi energi listrik melalui kegiatan PKM Teknik Elektro STT PLN yang telah dilaksanakan di Desa Sukawali, Kecamata Pakuhaji, Tangerang mensosialisasikan cara mengolah sampah menjadi suatu hal yang bermanfaat dan ramah lingkungan. 


\section{METODE PELAKSANAAN}

Metode yang digunakan untuk menjawab permasalahan atau mencapai tujuan kegiatan program pengabdian pada masyarakat (PKM) ini adalah dengan melakukan sosialisasi melalui tahaptahap sebagai berikut:

1. Persiapan

Persiapan dilakukan dengan mengadakan kesepakatan kerjasama dengan mitra, yaitu antara Tim PKM Teknik Elektro Sekolah Tinggi Teknik PLN dengan Kepala Desa Sukawali, Kecamatan Pakuhaji, Tangerang. Pihak mitra, dalam hal ini Desa Sukawali, Kecamatan Pakuhaji, Tangerang berkewajiban menyiapkan dan mengorganisir peserta pelatihan dan termasuk mempersiapkan tempat pelatihan yaitu aula Kantor Desa Sukawali, sedangkan kewajiban Tim P2M Teknik Elektro Sekolah Tinggi Teknik PLN berkewajiban mempersiapkan materi dan pelaksanaan sosialisasi ini.

2. Pelaksanaan

Pelaksanaan sosialisasi di Aula Kantor Desa Sukawali, Kecamatan Pakuhaji, Tangerang yang diikuti oleh \pm 30 peserta yang berasala dari masyarakat setempat. Sosialisasi ini diawali dengan penyampain materi oleh dosen Jurusan Teknik Elektro dan kemudian dilanjutkan tim dosen pengabdian, dan setiap selesai materi oleh pemateri langsung diadakan tanya jawab.

Pelaksanaan pelatihan sesuai kesepakatan mitra dengan tim pelaksana pengabdian, dibutuhkan waktu minimum 3 hari kerja.

\section{HASIL DAN PEMBAHASAN}

\subsection{Hasil Yang Dicapai}

Sosialisasi pengolahan sampah ini mendapatkan sambutan luar biasa dari peserta. Hal tersebut terlihat dari antusiasme masyarakat dalam ingin mengetahui pengolahan sampah ini dengan mengajukan banyak pertanyaan.

Hasil yang dicapai dari kegiatan Program Kemitraan Masyarakat Sosialisasi Pengolahan Sampah Menjadi Energi Listrik untuk masyarakat Desa Sukawali, Kecamatan Pakuhaji, Tangerang adalah:

a. Bagi kelompok sasaran, mendapatkan pengetahuan dan pelatihan pengolahan sampah sehingga sampah tidak lagi menjadi masalah dalam lingkungan bahkan akan memberikan manfaat.

b. Bagi Tim PKM, mempraktekkan ilmu dan keterampilan yang dimilikinya khususnya dalam bidang pengolahan sampah.

c. Bagi STT PLN, memperluas jaringan dan lebih mengenalkan STT PLN di masyarakat tentang perguruan tinggi teknik yang peduli lingkungan.

\subsection{Pembahasan}

Model pengelolaan sampah saat ini tergantung pada ketersedian TPA (Landfill) yang kapasitasnya terbatas dan menyebabkan banyaknya frekuensi truk sampah hilir mudik di jalan sehingga membuat pencemaran akibat bau busuk dan asap gas buang knalpot. Model Tempat Olah Sampah Setempat (TOSS) dalam kerangka Listrik Kerakyatan (LK) dapat menjadi alternatif untuk menjawab dilema TPA, karena sampah bisa dijadikan energi listrik di banyak tempat yang dekat dengan sumbernya.

Selain bermanfaat bagi lingkungan, TOSS bisa memberikan peluang bisnis dengan pendapatan dari Tipping Fee, pupuk, energi listrik, dan penjualan briket. Briket bisa dijual ke pembangkit LK 
sebagai bahan bakar dan ke PLTU atau pabrik yang menggunakan batu bara untuk mengubah abu terbang dan abu dasar menjadi batubara kembali atau menjadi material setara beton. TOSS akan membuka industri rakyat setempat, sehingga membuka lapangan kerja.

Konsepsi TOSS-LK yaitu dual system pengolahan sampah, yaitu pertama, Digester anaerobic. Sistem ini untuk mengolah sampah organik khususnya sisa makanan yang menjadi sumber utama bau sampah, hal ini bermanfaat untuk mengurangi bau busuk, lindi sebagai bahan untuk proses "peuyeumisasi" pembuatan briket, gas methan untuk kompor atau genset, pupuk cair. Kedua, Peuyeumisasi yaitu untuk mengolah sisa sampah anorganik setelah bahan yang bernilai (botol aqua dll) dipisahkan. Hal ini bermanfaat untuk mempercepat penyusutan sampah dan penghilangan bau.

Berikut ini adalah dokumentasi foto kegiatan pengabdian:

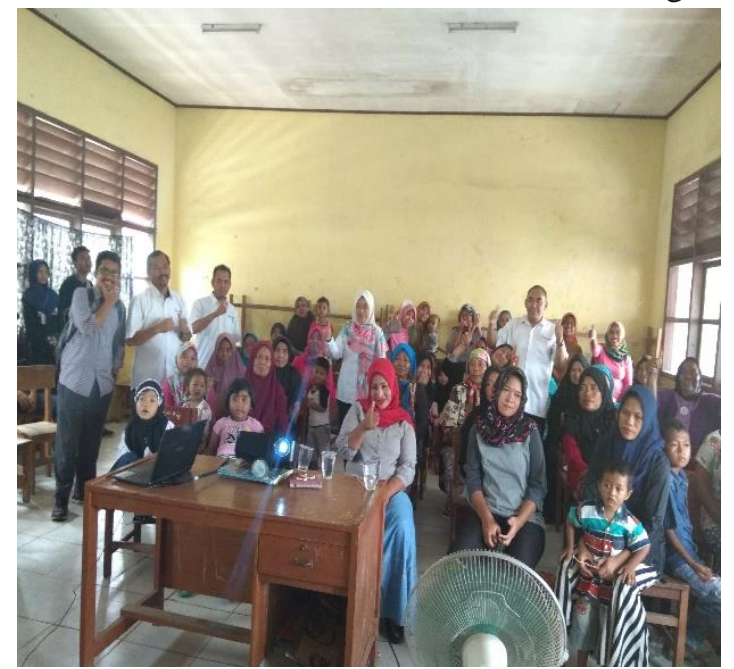

Gambar 1. Suasana Peserta Pelatihan

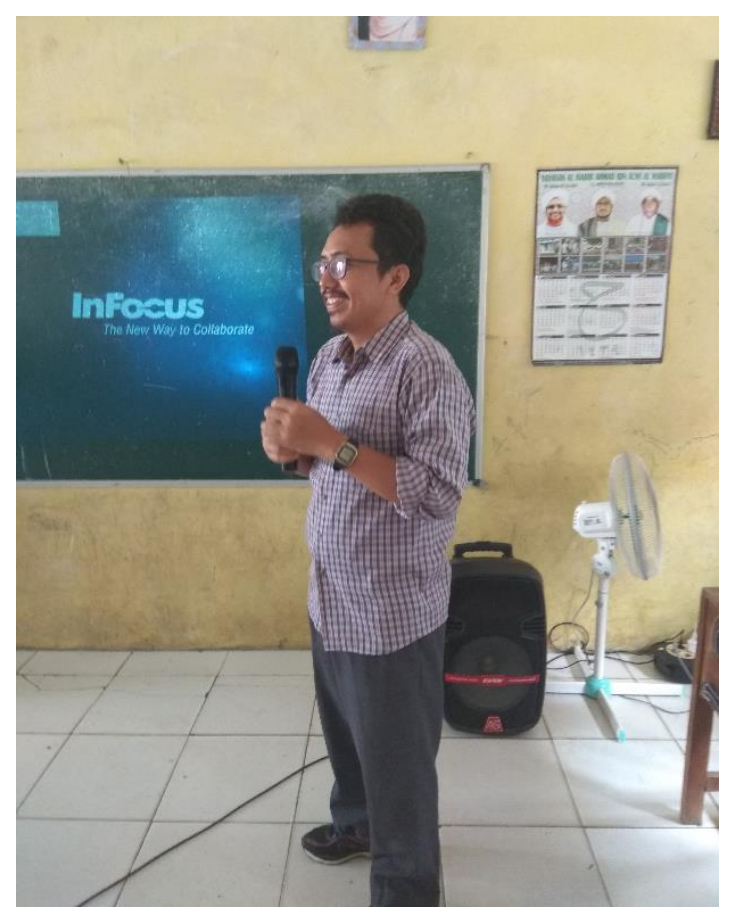

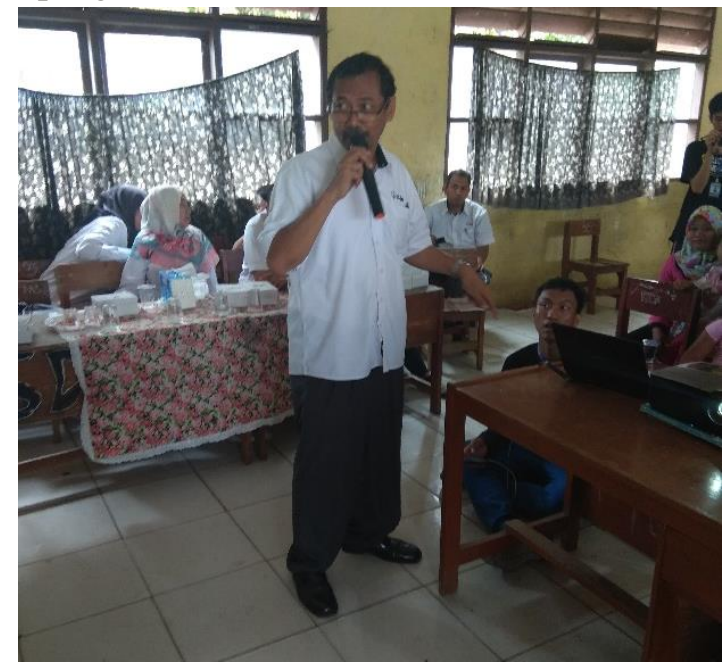

Gambar 2. Pemateri Sosialisasi

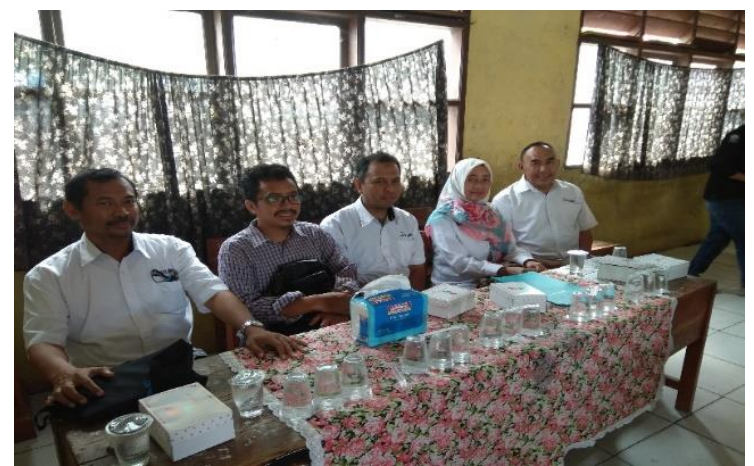

Gambar 3. Pemberi motivasi dan dosen pelaksana PKM 


\section{KESIMPULAN}

Dari kegiatan Pengabdian Pada Masyarakat yang telah dilaksanakan maka dapat diambil kesimpulan bahwa pelaksanaan kegiatan sosialisasi ini memberikan nilai tambah bagi masyarakat Desa Sukawali, Kec. Pakuhaji, Tangerang yaitu nilai tambah pengetahuan tentang pengolahan sampah yang baik dan bagaimana sampah itu tidak mengotori lingkungan tapi justru memberikan manfaat yang sangat berguna apabila dikelolah dengan baik misalnya sampah menjadi energi listrik. Selain itu, masyarakat Desa Sukwali, Kec. Pakuhaji sangat antusias untuk mengetahui cara pengolahan sampah ini.

\section{SARAN}

Permasalahan sampah yang sangat kompleks ditengah masyarakat Indonesia umumnya dan Kota Tangerang khususnya perlu mendapatkan sosialisasi yang masif dan intens untuk mengatasi permasalahan sampah ini sehingga diperlukan keterlibatan tidak hanya masyarakat desa tetapi bagaimana perangkat desa sampai pemerintah kota memberikan perhatian khusus tentang pengolahan sampah ini.

\section{UCAPAN TERIMA KASIH}

Terima kasih kami sampaikan kepada instansi STT PLN Jakarta yang telah mendanai kegiatan Pengabadian Kepada Masyarakat (PKM) ini melalui Lembaga Pengabdian Pada Masyarakat (LPPPM).

\section{DAFTAR PUSTAKA}

[1] CNN Indonesia, "CNN Indonesia," Cable News Network, Inc. A Time Warner Company, 25 04 2018. [Online]. Available: https://www.cnnindonesia.com/gaya-hidup/20180425101643282-293362/riset-24-persen-sampah-di-indonesia-masih-tak-terkelola. [Diakses 0603 2019].

[2] Litbang Kompas, “Kompas," PT. Kompas Cyber Media (Kompas Gramedia Digital Group), $27012016 . \quad$ [Online]. Available: https://properti.kompas.com/read/2016/01/27/121624921/Indonesia.Darurat.Sampah.. [Diakses 0603 2019].

[3] M. Ambari, "Mongabay," Mongabay, $0202 \quad 02$ 2018. [Online]. Available: https://www.mongabay.co.id/2018/02/02/kapan-indonesia-terbebas-dari-sampah/. [Diakses $06032019]$.

[4] D. Muhammad, "Republika," Republika, 0901 2014. [Online]. Available: https://www.republika.co.id/berita/nasional/jabodetabek-nasional/14/01/09/mz4rk9-sampahdi-kota-tangerang-masih-1500-ton-per-hari. [Diakses 0603 2019].

[5] A. W. Puspa, "Bisnis," Bisnis Indonesia, $16 \quad 10$ 2018. [Online]. Available: https://ekonomi.bisnis.com/read/20181016/44/849996/tempat-pembuangan-sampah-di-kotatangerang-ini-bangun-pembangkit-listrik-tenaga-sampah. [Diakses 0603 2019]. 